\section{Canadian Opinions on Publicly Financed Dental Care}

\author{
Carlos R. Quiñonez, DMD, MSc \\ David Locker, BDS, PhD, DSc, FCAHS
}

\section{ABSTRACT}

Background: Inequalities in oral health and care are long recognized in Canada, with public health environments increasingly focusing on issues of equity and access to care. How does Canada publicly insure for diseases that are largely preventable, minimally experienced by the majority, but that still cause tremendous suffering among the socially marginalized? We consider this dynamic by asking Canadians their opinions on publicly financed dental care.

Methods: Data were collected from 1,006 Canadian adults through a telephone interview survey using random digit dialling and computer-assisted telephone interview technology. Simple descriptive and bivariate analyses were undertaken to assess relationships among variables, with logistic regression odds ratios calculated for significant relations.

Results: Canadians support the idea of universal coverage for dental care, also recognizing the need for care to specific groups. Generally preferring to access public care through the private sector, Canadians support the idea of opting out, and expect those who access such care to financially contribute at point of service.

Conclusion: Support for publicly financed dental care is indicative of a general support for a basic right to health care. Within the limits of economy, the distribution of oral disease, and Canadian values on health, the challenge remains to define what we think is equitable within this sector of the health care system. This question is ultimately unanswerable through any survey or statistical means, and must, to become relevant, be openly promoted and debated in the social arena, engaging Canadians and their sense of individual and social responsibility.

MeSH terms: Dental care delivery; public opinion; access to health care; policy

La traduction du résumé se trouve à la fin de l'article.

Community Dental Health Services Research Unit, Faculty of Dentistry, University of Toronto, Toronto, ON

Correspondence and reprint requests: Dr. Carlos R. Quiñonez, Room \#521A, Community Dental Health Services Research Unit, Faculty of Dentistry, University of Toronto, 124 Edward Street, Toronto, ON M5G 1G6, Tel: 416-979-4908, ext. 4493, Fax: 416-979-4936, E-mail: carlos.quinonez@utoronto.ca

Acknowledgements: We thank the Social Science and Humanities Research Council of Canada and the Dentistry Canada Fund for their generous support, and Amir Azarpazhooh for research assistance.
I Canada, dental care is publicly insured (in some cases) if care is received in-hospital, or if one belongs to a particular institutionalized and/or atrisk population (e.g., those holding a staterecognized indigenous status, social assistance recipients and their dependents, some seniors and/or those with developmental disabilities). ${ }^{1}$ Publicly funded dental care now amounts to $6 \%$ of total dental expenditures, down from $7.7 \%$ in 1995 , decreasing steadily from an apex of roughly $20 \%$ in the early 1980 s. $^{2-4}$ This trend downwards is clearly observable in per capita expenditures for public care (Figure 1 ), and is contrasted by total dental expenditures that continue their increase, up from $\$ 1.3 \mathrm{~B}$ in 1980 , to $\$ 5.5 \mathrm{~B}$ in 1995 , now reaching an estimated $\$ 9.7 \mathrm{~B}{ }^{2,3}$

Decreases in the public financing of dental care may not be healthy in the long term, especially with mounting evidence linking oral disease to diabetes and aspiration pneumonias, and with research continuing into the possible linkages with cardiovascular disease and adverse pregnancy outcomes. $^{5-7}$ In effect, not only does there exist the potential to mitigate such resource-intensive and acute-care-based illnesses, there also remains the basic fact that oral ill health acts as a significant burden to the impoverished who suffer most of the disease and who experience most of the barriers to access. ${ }^{8}$ In this regard, there is a growing movement in Canadian public health environments to consider the question of equity and access to dental care. ${ }^{?}$

Dental professional, public health, and social welfare groups now routinely criticize the lack of social focus on this demonstrably important health condition. ${ }^{10-14}$ They argue that dentistry is ignored, receiving no mention in the Romanow Report, despite its being, in the same time period, the sole focus of a United States Surgeon General's report, wherein an analogous situation was deemed a 'silent epidemic.' ${ }^{15}$ In turn, Canadian governments appear to be responding, with new public financing initiatives in select provinces and municipalities, and with the creation of the Office of the Chief Dental Officer at the federal level. ${ }^{16-19}$

Yet in the midst of continual budgetary constraints, and with the increasing demands for pharmaceutical and home care services ${ }^{20}$ how does Canada publicly insure 
for diseases that are largely preventable? How do we, or should we, insure for diseases that are minimally experienced by a majority of the population, but that still cause an inordinate amount of pain and suffering among the socially marginalized?

A first step is simply to ask Canadians their opinions on publicly financed dental care. Surely, what Canadians prefer provides a basis for establishing a social direction..$^{20}$ Do Canadians perceive a role for government in the financing of dental care? Who, if anyone, should receive public coverage? Which treatments? How should they be financed? This study attempts to answer such questions, if only to begin debate as to the role of dental care within Canada's health care system.

\section{METHODS}

Cross-sectional and retrospective in design, data were collected from a representative sample of Canadians by means of a telephone interview survey $(\mathrm{n}=1006,>18 \mathrm{yrs}$; assumes maximum variance with a $95 \%$ confidence interval of $\pm 3 \%$ ). Using random digit dialling and computer-assisted telephone interview technology, a private firm was employed for data collection due to the technical demands of such an approach (i.e., generating random samples from a national listing of telephone numbers, person-hours required to undertake the survey in a reasonable timeframe). Receiving approval from a university ethics board, no personal identifiers were collected, and participation in the interview was taken to imply consent.

The 17-item questionnaire obtained data on: general dental care behaviours and perceived needs (e.g., when was the last time you visited a dentist? have you ever needed dental care but could not afford it? if so, what types of dental care?); opinions and experiences with the financing of dental care (e.g., should dental care be part of Medicare? how do you normally pay for dental care?); preferences for how publicly covered care should be structured (e.g., who and what treatments should be covered? should recipients be expected to cover a portion of costs?); and sociodemographic information (e.g., age, gender, income, education, location).

Data were analyzed using SPSS 11.0.4, and weighted relative to the provin-

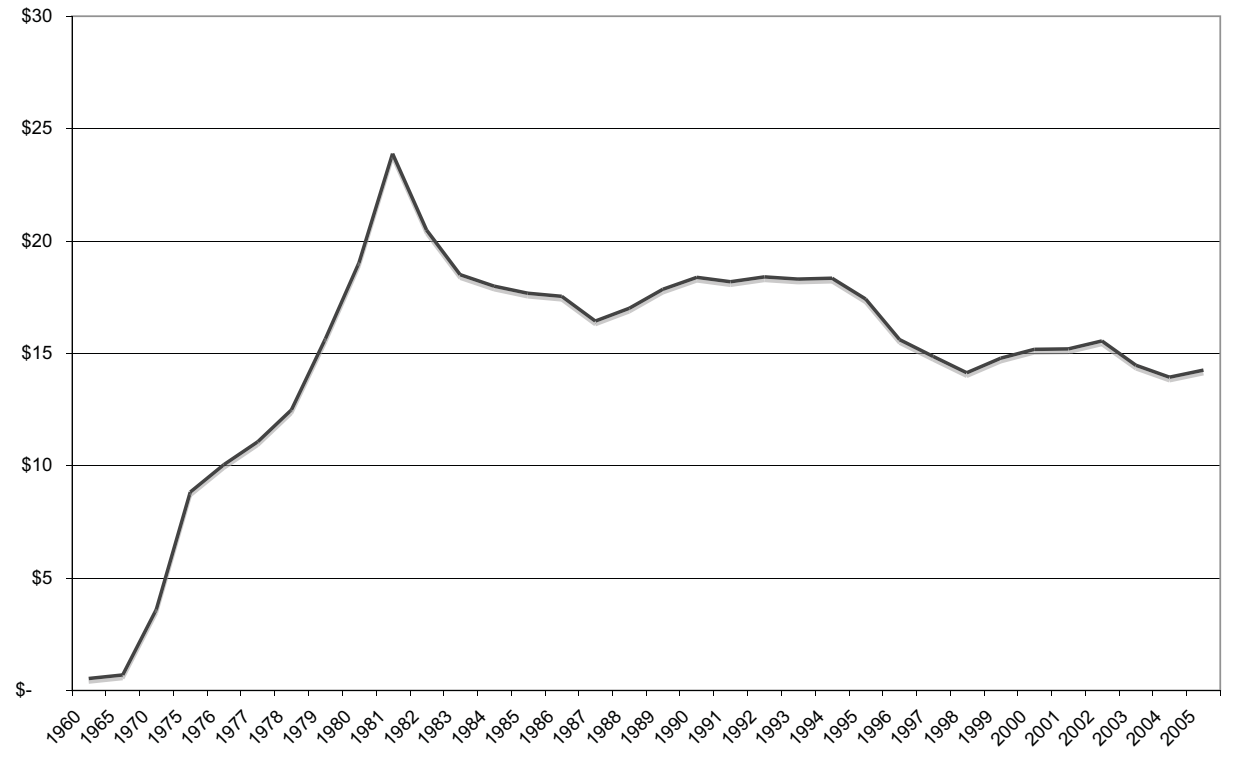

Figure 1. Per capita public dental expenditures in Canada, 1960/65/70, 1975-2005 (constant dollars)

\section{TABLE I}

Treatments Needed by Those Who Could Not Afford Dental Care

$\begin{array}{lcc} & \text { \% Responses } & \text { \% Respondents } \\ \text { Checkups } & 12.9 & 30.0 \\ \text { Cleanings } & 14.9 & 34.6 \\ \text { Fillings } & 15.2 & 35.3 \\ \text { Extractions } & 11.0 & 25.5 \\ \text { Dentures } & 6.1 & 14.1 \\ \text { Root canals } & 11.9 & 27.6 \\ \text { Gum surgeries } & 3.7 & 8.7 \\ \text { Crowns } & 8.8 & 20.4 \\ \text { Braces } & 6.0 & 13.8 \\ \text { Cosmetic treatments } & 2.8 & 6.5 \\ \text { Other } & 6.6 & 15.3\end{array}$

\section{TABLE II}

Who Should Be Eligible for Publicly Financed Dental Care?

Everyone
Children of the poor
All children
Anyone without private insurance
Persons on social assistance
Persons with physical and mental disabilities
Persons with Aboriginal status
Seniors
Persons in long-term care
The homeless
Other

\% Responses
36.9
4.4
9.9





7.1
7.1
7.0
3.3
9.0
5.4
5.3
3.5

\% Respondents
66.3
7.8
17.9
14.5
12.7
12.5
6.0
16.1
9.8
9.6
6.3

TABLE III

What Treatments Should Be Included in Publicly Financed Dental Care?

Checkups
Cleanings
Fillings
Extractions
Dentures
Root canals
Gum surgeries
Crowns
Braces
Cosmetic treatments
Other

\% Responses
13.3
12.7
12.7
10.8
9.5
10.1
9.5
8.4
7.8
3.4
1.8




\section{TABLE IV}

\section{Results of Logistic Regression Analyses*}

Gender Female

Male (reference)

Income

$<\$ 15,000$

$\$ 15,000$ to $\$ 29,999$

$\$ 30,000$ to $\$ 49,999$

$\$ 50,000$ to $\$ 69,999$

$\$ 70,000$ to $\$ 89,999$

$\geq \$ 90,000$ (reference)

History of cost-prohibitive dental care need Yes

\begin{tabular}{|c|c|c|c|}
\hline \multicolumn{2}{|c|}{ Bivariate } & \multicolumn{2}{|c|}{ Multivariate } \\
\hline $\begin{array}{l}\text { Odds Ratio } \\
{[95 \% \mathrm{Cl}]}\end{array}$ & $\mathbf{p}$ & $\begin{array}{l}\text { Odds Ratio } \\
{[95 \% \mathrm{Cl}]}\end{array}$ & $\mathbf{p}$ \\
\hline $1.8[1.3,2.6]$ & 0.001 & $1.7[1.1,2.7]$ & 0.018 \\
\hline $\begin{array}{l}5.4[1.6,18.5] \\
2.6[1.2,5.6] \\
2.0[1.1,3.7] \\
1.5[0.8,2.7] \\
1.1[0.6,2.1]\end{array}$ & $\begin{array}{l}0.006 \\
0.009 \\
0.02 \\
0.179 \\
0.698\end{array}$ & $\begin{array}{l}3.2[0.9,11.9] \\
1.9[0.8,4.4] \\
2.1[1.1,4.0] \\
1.1[0.8,2.2] \\
1.1[0.6,2.2]\end{array}$ & $\begin{array}{l}0.077 \\
0.146 \\
0.027 \\
0.216 \\
0.712\end{array}$ \\
\hline $2.1[1.3,3.4]$ & 0.002 & $2.1[1.2,4.0]$ & 0.013 \\
\hline $\begin{array}{l}3.9[1.5,9.7] \\
1.7[0.9,3.4] \\
1.4[0.8,2.7] \\
1.5[0.8,2.9]\end{array}$ & $\begin{array}{l}0.003 \\
0.084 \\
0.27 \\
0.203\end{array}$ & $\begin{array}{l}1.9[0.7,5.9] \\
1.1[0.5,2.3] \\
1.1[0.5,2.5] \\
1.3[0.6,2.8]\end{array}$ & $\begin{array}{l}0.218 \\
0.827 \\
0.739 \\
0.444\end{array}$ \\
\hline $\begin{array}{l}1.7[1.0,2.9] \\
1.7[1.1,2.5] \\
5.9[1.2,28.3]\end{array}$ & $\begin{array}{l}0.045 \\
0.01 \\
0.026\end{array}$ & $\begin{array}{l}1.7[0.9,3.3] \\
1.0[0.6,1.7] \\
2.6[0.5,13.6]\end{array}$ & $\begin{array}{l}0.119 \\
0.984 \\
0.244\end{array}$ \\
\hline
\end{tabular}

No (reference)

Education

Primary and high school without graduation

High school with graduation

Community college

University bachelors

Graduate degree (reference)

Insurance

Through municipal or provincial insurance

Directly out of my pocket

Through someone else's employment insurance

Through my employment insurance (reference)

Dependent variable: probability of thinking dental care should be included in Medicare $(\mathrm{No}=0, \mathrm{Yes}=1)$

cial/territorial population distribution. Simple descriptive analyses were undertaken for the sample as a whole and for subgroups based on socio-demographic characteristics. Chi-square tests and odds ratios were used to assess relationships between self-reported dental care behaviours, perceived needs, socio-demographic characteristics, and preferences for the financing and structuring of public care. Bivariate and multivariate logistic regression odds ratios were also calculated for a variety of outcomes (e.g., insurance status, history of a cost-prohibitive dental care need, positive response to the idea that dental care should be included in Medicare).

\section{RESULTS}

Consistent with data from the Canadian Community Health Survey, the National Population Health Survey, and the Joint Canada/United States Survey of Health, ${ }^{8,21,22}$ approximately $82 \%$ of Canadians report their oral health as good to excellent, while $70 \%$ of Canadians visit the dentist in any given year. In turn, nearly $60 \%$ access dental care through private insurance, $35 \%$ through personal financing, and $4 \%$ through public financing.

Importantly, and arguably pointing to the role of employment-based insurance, close to $74 \%$ of Canadians do not find dental care cost-prohibitive; yet there remain $26 \%$ who do. Of the latter, on average, 2 items were deemed unaffordable per respondent, with check-ups, cleanings and fillings mentioned by most, and extractions by $25.5 \%$ (Table I).

Counterposed here are the $83 \%$ of Canadians who think dental care should be part of Medicare. Yet when asked exactly who should be included, and given the options of 'everyone,' and groups recognized as experiencing some level of social marginalization (e.g., children, seniors, social assistance recipients, the homeless), opinions on universal coverage appear to change. Approximately two thirds now include everyone, and of the remainder, on average, 2 groups are noted as requiring public coverage per respondent, with $17.9 \%$ noting 'all children', $16.1 \%$ 'seniors', $14.5 \%$ 'anyone without private insurance', among various others (Table II).

When asked which treatments should be publicly financed, on average 6 items are noted per respondent, with most mentioning check-ups, cleanings and fillings, followed by a wide variety of services (Table III). In addition, approximately $75 \%$ of Canadians expect those accessing publicly financed care to pay for some portion of treatment, and close to $80 \%$ feel that opting out of public programming should be an option. Two thirds of Canadians also prefer accessing publicly financed care through a private practitioner, as compared to $19 \%$ through a community clinic, and $7.6 \%$ through a dental school.
Important to any social movement aimed at equity and access to dental care is the question of what determines one's response to perceiving dental care as a social right. Modelled predicatively then, the idea that dental care should be included in Medicare is associated with gender, income, education, insurance coverage, and the experience of an historical costprohibitive dental need (Table IV). So while the majority of Canadians are in agreement, there still exists a socio-demographic gradient to this dynamic. Further, when controlling for the influence of all covariates simultaneously, only gender, income, and the experience of an historical costprohibitive dental need remain as predictors (Table IV).

\section{DISCUSSION}

Do Canadians support ensuring some level of social right to dental care? Do they perceive a role for government in the financing of such care? It appears that they do, with a significant majority promoting the idea of universal coverage. Canadians also promote care for specific groups, recognizing children and seniors in particular, among others on the social margin. A large variety of services are deemed publicly accessible, from basic exams, cleanings and fillings, to crowns and orthodontic care. Very few Canadians perceive a public role in cosmetically oriented care, with many 
supporting the idea of co-payments and opting out. Maintaining current mechanisms of delivery, most also prefer accessing publicly financed care in the private sector. In effect, Canadians support the idea of dental care as a social right, are generous as to who should have this right and what should be accessible through it, and in their collectivism, tend towards individual choice and responsibility.

This parallels other research on Canadian opinions of health care, where Canadians are consistently generous with the notion of comprehensiveness of care: by $1998,77 \%$ and $85 \%$ supported the inclusion of pharmacare and home care, respectively; ${ }^{20}$ and by 2006, 91\% thought coverage of publicly insured services should extend to home care, long-term care, mental health care and drug benefits. ${ }^{23}$ Similarly, when asked how pharmacare and home care should be financed, Canadians preferred cost-sharing between patient and government. ${ }^{20}$ Yet contrary to the now-evident support for publicly financed dental care, a past "review of public opinion surveys and other sources [did] not find any overwhelming movement to include other services under the Canada Health Act." 20

The idea of universal coverage for dental care is immediately faced with limits. Economically, with close to $\$ 10 \mathrm{~B}$ in expenditures every year, it is unknown what portion of services could reasonably constitute public goods, and which services, if any, governments are ready to finance. Canadian opinions also exist in an environment wherein the majority already enjoy coverage and experience minimal disease, alongside social values on health that tend to view oral hygiene as principally individually based. To be sure, what safety net should be available to someone who does not brush his or her teeth? This may be, on the surface, a harsh account of oral health behaviours, their population distribution, and the social responses to it, yet one need only consider the billions spent on cardiac care every year to see how complex these issues may actually be. Again, these are significant expenditures that are constituted by largely preventable conditions, and that similarly link to routine health behaviours; a complexity that is often under-determined in our social discussions on dental care.
Most importantly, this is not solely a problematic of extreme inequity, but one that affects the average Canadian. Indeed, there is public access for many on the social margin, but little for those working poor and limited-income families ineligible to receive public benefits because of employment, yet working in minimum- or middle-wage-earning jobs without the presence of employment-based dental insurance.

Within these limits, Canadian support for publicly financed dental care is best approximated as indicative of a general support for a basic right to health care. The challenge remains to define what we think is equitable access within this sector of Canada's health care system. Ultimately, this is a question that cannot be answered through any survey or statistical means, and one that must, to become relevant, be openly promoted and debated in the social arena, engaging Canadians and their sense of individual and social responsibility.

\section{REFERENCES}

1. Stamm J, Waller M, Lewis D, Stoddart G Dental Programs in Canada: Historical Development, Current Status and Future Directions. Ottawa, ON: Health and Welfare Canada, 1986.

2. Canadian Institute for Health Information. National Health Expenditure Trends, 19752005. Ottawa: CIHI, 2005.

3. Leake J. Expenditures on dental services in Canada, Canadian Provinces and Territories 1960-1980. J Can Dent Assoc 1984;5:362-68.

4. Quiñonez C, Grootendorst P, Sherret L, Azarpazhooh A, Locker D. An environmental scan of Provincial and Territorial public dental programs in Canada. Community Dental Health Services Research Unit, University of Toronto, unpublished data, 2006.

5. Slavkin H, Baum B. Relationship of dental and oral pathology to systemic illness. JAMA 2000;284:1215-17.

6. Azarpazhooh A, Leake J. Systematic review of the association between respiratory diseases and oral health. Periodontol 2006;77(9):1465-82.

7. Pihlstrom B, Michalowiscz B, Johnson N. Periodontal diseases. Lancet 2005;366(9499): 1809-20.

8. Locker D, Matear D. Oral Disorders, Systemic Health, Well-Being and the Quality of Life. Toronto, ON: Community Health Services Research Unit, 2000.

9. Armstrong R. Access and care: Towards a national oral health strategy - Report of the symposium. $J$ Can Dent Assoc 2005;71(1):19-22.

10. McNally M. The Silent Epidemic: Evaluating Continuity of Care and Policies for the Oral Health Care of Seniors. Halifax, NS: Canadian Health Services Research Foundation Final Report, 2004

11. Canadian Dental Hygienists Association. Access Angst: A CDHA Position Paper on Access to Oral Health Services. Ottawa: CDHA, 2003.

12. Toronto Dental Coalition. Brief to the Commission on the Future of Health Care in Canada. Ottawa: TDC, 2002.

13. Canadian Dental Association. Romanow Report: Where is Oral Health Care? News Release. Ottawa: CDA, November 28, 2002.

14. Federal, Provincial, Territorial Dental Directors. Oral Health: Its Place in a Sustainable Health Care System for Canadians, Brief to the Commission on the Future of Health Care in Canada. Ottawa: FPTDD, 2002.

\section{RÉSUMÉ}

Contexte : Au Canada, on reconnait depuis longtemps que des inégalités existent en matière de santé bucco-dentaire, les milieux de la santé publique insistant de plus en plus sur les questions d'équité et d'accès aux soins. Comment le Canada peut-il se permettre d'offrir des services assurables contre des problèmes de santé facilement évitables qui, même s'ils ne touchent qu'une infime partie de la population, causent néanmoins d'énormes souffrances chez les personnes en marge de la société? Nous nous sommes penchés sur la question en sondant l'opinion des Canadiens sur les soins dentaires subventionnés par l'État.

Méthode : Nous avons recueilli des données auprès de 1006 Canadiens adultes par le biais d'un sondage téléphonique à composition aléatoire assisté par ordinateur. De simples analyses descriptives et bivariées ont été effectuées afin d'évaluer les relations entre les variables, en calculant un rapport de cotes par régression logistique pour les relations significatives.

Résultats : Les Canadiens sont en faveur d'une couverture universelle des soins dentaires et reconnaissent également les besoins en soins dentaires de certains groupes. S'ils préfèrent généralement avoir accès aux soins publics par la voie du secteur privé, ils sont favorables à l'idée d'une option de retrait et s'attendent à ce que ceux qui accèdent à de tels soins contribuent financièrement au point de service.

Conclusion : L'appui accordé au financement public des soins dentaires témoigne de la reconnaissance générale du droit fondamental aux soins de santé. Compte tenu des limites budgétaires, de la répartition des problèmes de santé buccale et des valeurs des Canadiens relativement à la santé, il reste à définir ce que nous jugeons être équitable pour ce secteur du réseau de la santé. Une réponse à cette question ne saurait être obtenue par le biais d'un sondage ou de données statistiques. Pour être pertinente, la question doit être présentée et débattue dans l'arène sociale et faire ainsi appel aux Canadiens et à leur sens des responsabilités individuelles et sociales. 
15. United States Surgeon General. Oral Health in America: A Report of the Surgeon General. Washington, DC: Government of the United States of America, 2000.

16. Ministry of Health Services, Ministry of Human Resources. Enhanced dental program benefits British Columbians. News Release. Vancouver, BC: Ministry of Health Services, Ministry of Human Resources, March 14, 2005.

17. Manitoba Health. Health Minister announces new initiatives to reduce tooth decay, lower paediatric dental wait times. News Release. Winnipeg, MB: Manitoba Health, November 10, 2005.

18. Government of Alberta. Enhanced benefits for seniors announced. News Release. Edmonton, AB: Government of Alberta, August 12, 2004.

19. Government of Canada. Chief Dental Officer for Health Canada. News Release. Ottawa: Government of Canada, October 28, 2005.

20. Vail S. Canadians' Values and Attitudes on Canada's Health Care System. Ottawa: The Conference Board of Canada, 2000.

21. Statistics Canada. Canadian Community Health Survey. Ottawa: Health Division, Health Reports, 2003.

22. Statistics Canada, Centers for Disease Control. Joint Canada/United States Survey of Health. Ottawa: Statistics Canada, Health Analysis and Measurements Group, 2003.

23. Ipsos Reid. Canadians on Healthcare. News Release, January 2006.

Received: September 27, 2006

Accepted: March 6, 2007

\section{Coming Events / Activités à venir}

To be assured of publication in the next issue, announcements should be received by November 30, 2007 and valid as of December 31, 2007. Announcements received after November 30, 2007 will be inserted as time and space permit.

Pour être publiés dans le prochain numéro, les avis doivent parvenir à la rédaction avant le 30 novembre 2007 et être valables à compter du 31 décembre 2007. Les avis reçus après le $\mathbf{3 0}$ novembre 2007 seront insérés si le temps et l'espace le permettent.

\section{OPHA 2007}

Public Health: Who's at Risk? What's at Stake?

Ontario Public Health Association; co-hosted by Toronto Public Health

18-21 November 2007

Toronto, ON

Contact: OPHA

www.ophaconference.ca

Health Human Resources 2007: Connecting Issues and People

The Canadian Institute for Health Information (CIHI), the Canadian Institutes of Health

Research (CIHR), Health Canada, and the Public Health Agency of Canada (PHAC)

4-6 December 2007

Ottawa, ON

Contact: $\mathrm{CIHI}$

www.cihiconferences.ca

Canadian Public Health Association 2008

Annual Conference / Conférence annuelle 2008 de l'Association canadienne de santé publique

Public Health in Canada: Reducing Health Inequalities Through Evidence and Action / Vers une réduction des inégalités en santé par la recherche et l'action

1-4 June/juin 2008

Halifax, NS/N-É

Contact/Contacter :

CPHA Conference Services

Service des conférences de l'ACSP

E-mail/Courriel : conference@cpha.ca www.cpha.ca

$5^{\text {th }}$ World Conference on Breast Cancer Heart, Soul, \& Science: "It's a Small World After All"

4-8 June 2008

Winnipeg, $\mathrm{MB}$

Contact: Tel: 204-480-4588

E-mail:mail@wcbcf.ca

www.wcbcf.ca $18^{\text {th }}$ World Conference on Disaster

Management

Resiliency - Individual, Community, Business

The Canadian Centre for Emergency

Preparedness

15-18 June 2008

Toronto, ON

Contact: www.wcdm.org

International Nursing Research Conference Facing the Challenge of Health Care Systems in Transition

29 June-3 July 2008

Jerusalem, Israel

Contact: Diesenhaus Unitours - Convention

Department

Tel: 972-3-5651313 Fax: 972-3-5610152

E-mail:meetings@diesenhaus.com

www.d-convention.com/israelnursing

Beyond the Horizon

$74^{\text {th }}$ Annual Educational Conference of the Canadian Institute of Public Health Inspectors (CIPHI)

20-23 July 2008

St. John's, NL

Contact: www.ciphi.ca/events.htm

$29^{\text {th }} \mathrm{ICOH}$, International Congress on Occupational Health / $29^{\mathrm{e}}$ CIST, Congrès International de la Santé au Travail Occupational Health: A Basic Right at WorkAn Asset to Society / Santé au travail : un droit fondamental au travail - un atout à la société 22-27 March/mars 2009

Cape Town, South Africa / Afrique du Sud Contact: Congress Secretariat / Secrétariat du Congrès

Tel/Tél : +27(0)21-938-9238/9245/9082/9651

Fax/Téléc : +27(0)219332649

E-mail/Courriel : admin@icoh2009.co.za www.icoh2009.co.za 